\title{
Problems of a Declining Hungarian Birth Rate: A Historical Perspective
}

\section{Ildikó Szántó}

\begin{abstract}
In contrast to its immediate neighbors, for over a century Hungary has had a seriously declining birth rate. This paper aims to provide an overview of this anomaly through a historical perspective by considering the major findings of a series of demographic studies that identify the key factors behind falling levels of fertility. It does so by focusing on four major periods. The first period covers the era prior to the demographic transition that commenced before 1880, when the demography was characterized by high birth rates and high death rates. The second period is one of demographic transition, between 1880 and 1960 coinciding with modernization, and is the period when death rates fell, while at the same time being accompanied by a decrease in birth rates. The third period is the post-transitional era of 1960-1980. The fourth covers the post-socialist change of 1990-2010. Hungary was the first country in Europe after the Second World War in which the level of fertility declined below a level of simple replacement of the population, which is less than 2.1 births per woman. Since 1981 the population has been declining by about $0.15-0.20$ percent per year, and currently fertility in Hungary is one of the lowest in Europe. The Hungarian age structure will become increasingly problematic as the fertile age group of the population continues to shrink.
\end{abstract}

Keywords: Demographic Transition in Hungary, Low Fertility Rates, Replacement Level, Ageing of Population.

Biography: Ildikó Szántó received her M.A. degree in History from Macquarie University, N.S.W. She has taught interdisciplinary courses focusing on the ideological movements of the twentieth century in East-Central Europe at the Budapest University of Economic Sciences, Pázmány Péter Catholic University, and the Budapest Business School.

This paper focuses on Hungary's anomalous situation within Europe, of having had a substantially declining birth rate since 1880 . It does so by considering the major demographic findings that help to explain this decline, and to identify the key factors behind falling levels of fertility by focusing on four major historical periods. The first period covers the time prior to the demographic transition that commenced in 1880, and is based on eighteenth-century registers, at a time when Hungary's demographic pattern was characterized by high birth rates and high death rates. This is followed by the period of demographic transition, which occurred between 1880 and 1960, and which coincided with modernization as death rates fell due to improvements in health care and sanitation, while also being accompanied by a decrease in birth rate. The third, 
Szántó, Ildikó. "Problems of a Declining Hungarian Birth Rate: A Historical Perspective." Hungarian Cultural Studies. e-Journal of the American Hungarian Educators Association, Volume 7 (2014): http://ahea.pitt.edu DOI: 10.5195/ahea.2014.1

the post-transitional period of 1960-1980, and the fourth, the post-socialist changes of 19902010, were both marked by a continuous fertility decline except the mid-1970s when the government population policy resulted temporarily in an increased birth rate. Apart from that brief flurry in the mid-1970s, the hallmark of the Hungarian post-transitional demographic period was that it continued to show a steady decline in fertility with the death rate being higher than the birth rate. The Hungarian lowest-to-low fertility figures are similar to most other East Central European data; while Hungary currently has one of the lowest birth rates and the fourth highest death rates in the European Union (Eurostat 2013; Kapitány and Spéder 2012: 33). Hungary was the first country in Europe after the Second World War in which the level of fertility declined far below a level of simple replacement of the population; that is, less than 2.1 births per woman. In 1962, at the time of the lowest point in this decline, the birth rate was 12.9 and the total fertility rate (TFR) was 1.79 (Hungarian Central Statistical Office - KSH, 1978). In other words, 12.9 people were born for every thousand people in the population. The TFR is a more direct measure of the level of fertility than the crude birth rate, since it refers to births per woman. This indicator shows the potential for population change in the country as it expresses the number of children born to women, between the ages of 15 and 49, in their fertile period, per thousand. Since 1981, the death rate has been higher than the birth rate, which means that from 1990 onwards the population has been declining by about $0.15-0.20$ percent per year. The TFR data was consistently below 1.3 between 2000 and 2004, where the average age at childbearing was 30 , and currently it is only 1.4. If this rate continues, the demographic forecasts are that the population will halve every 45 years (Kapitány and Spéder 2012: 32). Provided the current age structure of the population remains continuous into the future, Hungary, like other European countries, will have to come to terms with the fact that one-third of its population will be over the age of 65 by 2060 . Hungarian society already shows increased ageing, which will further deteriorate as the fertile age group of the population continues to shrink, a trend set in place since 1981 (The World Factbook 2013).

The period before the demographic transition, from the conclusion of the Peace Treaty of Szatmár in 1711 until the Compromise of 1867, may be regarded as a time of great transformation, when the development of manorial farming and an increased production of goods required a growth of a labor force. The lack of population was one of the essential problems of eighteenth century Hungary, a direct consequence of the previous 170 years of Ottoman rule, when almost as much as half of the original population perished (Lendvai 2003: 99). The famous English traveler, Lady Montague, who passed through the country in 1717 described Hungary as "a land that is covered by forests and it is a paradise for game and birds." She also writes that the first explorers of North America and Canada wrote in a similar vein about the sparsely populated lands of the New World. This is very like the accounts of twelfth century travelers in whose descriptions one can hardly find any mention of agriculture between Buda and Györ (Marczali 1888: 227).

At the beginning of the eighteenth century Hungarian population figures were estimated on the basis of registers that determined the number of taxable persons as well as those who could be conscripted into the Imperial Army (Acsády 1896: 294-295). This was followed by more accurate demographic surveys which were ordered by Joseph II in 1785-87. The censuses carried out after 1787, and the Austrian censuses of 1850 and 1857, showed a continuous increase in the population as well as an increase in the birth rate from the 1870s till the 1880s. Significantly, the period before the demographic transition was characterized by a low total population, but one that was balanced due to a combination of high birth rates and high death 
Szántó, Ildikó. "Problems of a Declining Hungarian Birth Rate: A Historical Perspective." Hungarian Cultural Studies. e-Journal of the American Hungarian Educators Association, Volume 7 (2014): http://ahea.pitt.edu DOI: 10.5195/ahea.2014.1

rates, although the population counts in the eighteenth century showed some alarming features. In particular, there was insufficient population in the agriculturally richest areas, especially in southern Hungary, and in the central middle plains, where the Magyar inhabitants were wiped out as a result of the Ottoman occupation and the continuous warfare along the military frontier. The consequent loss of population is illustrated by the fact that in 1720 tax-paying households cultivated less than five percent of the land throughout the country, showing that it was people who were in short supply and not arable land (Dávid in Kovacsics 1963: 156).

The depopulated regions of Hungary were resettled mainly in the eighteenth century, which is often called the second foundation of the State. It was a period of significant demographic movement, with both internal colonization and migrations from the Balkans and the German lands. The internal colonization meant a natural migration of Serbs northwards, of Slovaks southwards, an influx of Romanians from Moldavia and Wallachia into Transylvania, as well as a large scale settlement of German speaking population, mainly Swabians (Jászi 1986: 147,153). From the beginning of the eighteenth century more than four hundred new settlements were listed, and these were directly financed by the Habsburgs as part of the official colonization policy of Vienna (Acsády 1896: 41). Marton Schwartner and Ignác Acsády, the pioneers of Hungarian statistical studies, pointed out a major change that resulted in the ethnic composition of Hungary, which was to the disadvantage of Magyar population, reducing it to less than half of the total population.

The overall rate of increase in population between 1787 and 1850 was over five percent per annum but this growth was only noticeable from the late 1840s onwards, with virtually no natural growth earlier in this period due to the enormous loss of population that was a result of warfare and epidemics (Mérei and Vörös 1980: 473; Jászi 1986: 147, 153). Hungary lost two percent of its male population in the Napoleonic Wars between 1806-20, and this was followed by the cholera epidemics of 1830-32 and 1836-37, when a quarter of a million people died (Mérei and Vörös 1980: 474). The mortality rate in the Habsburg lands including Hungary was most unfavorable compared with the Western European countries of the period, as the high death rates resulted from not one but often several epidemics occurring concurrently. At the same time, general malnutrition and famine were prevalent, such as occurred in 1847 in the poverty stricken, mountainous eastern regions which also helped to explain especially high mortality rate among children below the age of three (Mérei and Vörös 1980: 475).

Hungary continued to have the lowest population density in the Habsburg Empire, with regional differences becoming far more significant by the 1840s than in the previous decades (Mérei and Vörös 1980: 481). The increase in the population of towns in the Great Plain and its southern fringes as well as in the northern counties was the most obvious feature of the population movement of the period, as these rural-market towns offered free legal status and pesonal freedom to former bonded serfs as the result of Joeph II's Imperial Patent of 1785. The partial emancipation of the peasants was an important contributing factor to the natural increase of population. Although the emancipation did not give ownership of the land to former serfs, it did promote the development of a new class of tenant landholders, and enabled the growth of larger families mainly in the eastern part of the Great Plain (Jászi 1986: 146). Unlike the situation in the eighteenth century, there was no significant large-scale immigration into Hungary in the nineteenth century, with the exception of Jewish immigration. This occurred mainly in the northern and eastern counties, where the population growth was due both to the influx of Jewish settlers mainly from Moravia and Galicia as well as to the natural increase in the local population (Mérei and Vörös 1980: 474). In spite of the overall uneven population density and the 
Szántó, Ildikó. "Problems of a Declining Hungarian Birth Rate: A Historical Perspective." Hungarian Cultural Studies. e-Journal of the American Hungarian Educators Association, Volume 7 (2014): http://ahea.pitt.edu DOI: 10.5195/ahea.2014.1

significant population losses suffered through poverty and epidemics, by the beginning of the nineteenth century the overall growth in population was remarkable as total population doubled. Hungary was a latecomer to modernization, as feudal privileges were only abolished in 1848; moreover, the aristocracy, the government, and the Church retained a tight hold on the land well into the twentieth century. By the second half of the nineteenth century the process of acquiring the communal grazing grounds as well as forests by large estate holders was completed as landlords forcibly increased the size of their estates to the detriment of the peasantry (Kiss 1985: 481). From the 1850s, landless peasants became more numerous as "dwarf prpoperties" - that is less than seven acres per family - made up more than half of the landholdings, and these did not even represent six percent of the total arable land. Assuming the average of four or five offspring per family, a peasant farmer would become landless within a generation (Kovács and Katus 1979: 605). The increasing problems of the property subdivisions of small and medium-sized peasant holdings and the uneven and inefficient use of agricultural labor exacerbated the shortage of manpower, especially by the 1880s, which coincided with the effect of the economic depression of 1873, as well as with a series of cholera epidemics. In the period of 1870-90, the number of small and dwarf holders decreased by more than 100,000 as a result of the emancipation of the peasants as well as the agricultural depression (Kovács and Katus 1979: 1111, 1117). It was therefore not surprising that the 1869 and 1880 censuses showed a lower level of increase in population growth of less than twelve percent, expressed as a yearly average of a mere half percent, compared with the German figures for the same period, and where the agricultural population continued increasing until 1914 (Kovacsics 1963: 243,320; Knodel 1974: 117). The Hungarian data was a third of the average European growth (Kovács and Katus 1979: 921,1123). In the second half of the nineteenth century, Hungarian population growth could not be compared to the increased birth rate of a more advanced country, such as Germany, which from the beginning of the nineteenth century had an extremely high birth rate, while mortality simultaneously remained low (Cipolla 1973: 90,121).

The period of demographic transition in Hungary between 1880 and 1960 is viewed in two stages, between 1880-1945 and 1945-1960, which coincided with industrialization and modernization. By 1890 death rates fell due to improvements in health care and sanitation, and concurrently a gradual decrease in live births was registered (Klinger 1980: 77, 82). The beginning and the most important phase of the demographic transition was from the late 1880s to the First World War, when the death rates were falling, while the birth rates remained at a high level, but only for less than a decade. The Hungarian demographic transition differed from the general Northern and Western models, as the Hungarian data showed a brief period of increased high birth rate, while the mortality rate only started to improve from the 1880 s onwards (Andorka 1987: 271). The birth rate peaked between 1876 and the 1880s, and the census data of 1890-1910 indicated that death rates fell. The previous increased birth rates were still significant in the age structure indicating population growth for a relatively short period of barely more than a decade, from the mid-1880s to 1900 .

The census of 1890 was the first reliable one, and also provided data that earlier counts had ignored, such as food consumption per head of population, and a comparison of various age groups within the Monarchy. This census also produced data on uneven birth, death and child mortality rates, and the effect of emigration (Ráth 1983: 43). It was found that the birth rate in Transylvania and in the Transdanubian counties were below the national average, in contrast to the area on the left bank of the Danube. The uneven birthrate was attributable to the Transylvanian mountainous topography related to poor agricultural land; however, this did not 
Szántó, Ildikó. "Problems of a Declining Hungarian Birth Rate: A Historical Perspective." Hungarian Cultural Studies. e-Journal of the American Hungarian Educators Association, Volume 7 (2014): http://ahea.pitt.edu DOI: 10.5195/ahea.2014.1

apply to the Transdanubian counties. In general, the Transdanubian counties followed the Western European pattern of marriage rate and customs, including marrying at a later age, which in turn affected birth rates, and resulted in smaller families when compared with the population on the left bank of the Danube, where the birth rate was more similar to the national average (Hajnal 1965: 102-103). Further demographic variations were mainly due to emigration from upper and lower area of the Tisza river, mainly from the south-eastern part of the country (Puskás 1975: 6, 17). Since population movements were carefully recorded from 1876 on, the continuing gradual decrease in live births in the area of present-day Hungary can be clearly demonstrated, with the number of live births in 1890 being about 10 percent less than in 1880. At the same time, there was a steady increase in the age of entry into first marriage: in 1880 and 1890 twentyone, in 1900 and 1910 above twenty two years of age and this, also, naturally affected the fertiltiy rate (Dányi 1977: 67).

There were several reasons for the falling birth rate at the beginning of this demographic transition, namely the immediate impact of emigration, of the increase in the age of entry into first marriage, and of the spread of a practice of a deliberate birth control. Well before the 1900s, demographers had highlighted the poor living standards of the agricultural population and the effect of this on the birth rate, with previously prosperous villages ceasing to grow. Falling birth rates had already been recorded as early as the late eighteenth century in south-western Hungary, in the Ormánság where an anonymous public servant commented on the census of 1777 and enclosed his findings stating that "four couples hardly produce a child a year..." (Dányi 1960: $172,184)$. Beyond a doubt, he said, the reason for this was that "the parents realized their inadequate means of feeding and providing for the offspring and putting aside God`s law in the sexual act of marriage, they prevent conception and procreation.” (Dányi 1960: 188).

The peasant landholders in the Ormánság villages were well-off in the1800s as they had more common land and forests than previously but by the 1880s these lands were expropriated or legally restored to the surrounding large landowners. The shortage of available land made them act so as to avoid the plight of landlessness. Consequently, birth control within marriage and the practice of crude abortions, which were often carried out by members of the family, became widespread in the region (Buday 1909:15; Kodolányi 1922: 17; Fülep 1929: 4,15; Andorka 1969: 1245). Initially a small number of children per family became the norm, but this soon developed into a custom of having a single child only as fertility limitation was seen as the answer to avoiding subdivisions of the inherited land. The notion, common in some other countries, that land had to be kept as a single entity for the eldest or for the youngest male offspring, while the rest of the children would seek work as agricultural laborers on large estates, was alien to the traditional peasant mentality, as even the small peasant allotments were used as a means of ensuring the independence of all of the offspring within a family. Although in the Ormánság adult members of the family could have migrated to other parts of the country, this possibly would have meant the separation from their Protestant community and therefore few if any families considered this possibility (Andorka 1987: 269). Elsewhere, the custom of one-child families appeared irrespective of denomination, simply relating to farming conditions and the lack of available land for purchase. The one-child syndrome was most noticeable in the Protestant villages of Baranya, although similarly birth control was practiced in the primarily Catholic Transdanubian villages in Somogy and Sárköz, the Catholic German villages of the south, Bácska-Bánát and in the Orthodox Romanian villages of Krassó-Szörény and Hunyad. The "one child family" syndrome was rooted in economics, invariably tied to the lack of available arable land, especially where peasantry relied on animal husbandry since the use of 
Szántó, Ildikó. "Problems of a Declining Hungarian Birth Rate: A Historical Perspective." Hungarian Cultural Studies. e-Journal of the American Hungarian Educators Association, Volume 7 (2014): http://ahea.pitt.edu DOI: 10.5195/ahea.2014.1

communal lands had contracted considerably by the end of the nineteenth century (Andorka 1987: 264; Dányi 1977: 74).

Although the decades between 1880 and 1910 comprised a period of rapid industrialization in Hungary, as American wheat reached European markets at substantially lower prices than Hungarian grain, the main Hungarian agricultural export was threatened and never regained its earlier competitive position. Consequently the decline in grain sales affected rural areas in particular and caused a somewhat delayed pattern of marriage and a decrease in live births (Lengyel et al. 1982: 108). While there were overall improvements in the economic conditions and a small increase of acreage in small and middle holdings, conditions nevertheless remained bleak for the vast majority of the households without access to adequate land or alternative employment. The agricultural crisis in the 1890s excacerbated the exisiting poverty of the smallholders and especially of the landless strata, the agricultural laborers. At the same time, the 1890 census confirmed the regional differences of uneven population growth, which stemmed primarily from the effect of the earlier, eighteenth-century resettlement of central Hungary. In comparison with other European data in the 1880-1890 decade, Hungary had the highest birth rate, possibly the highest death rate as well, and the highest child mortality rate up to the age of 15.3, all of which implied the impoverished state of the Hungarian peasantry (Ráth 1983: 63). Birth control within marriage was one of the answers to the agricultural crisis and, just as the initial level of population increase was uneven, so too was the pace of decline when the Hungarian fertility rate began to drop after 1890 (Demény 1972: 153-172). Small and medium holdings were the ones which primarily limited their number of offspring, which indicated widespread birth control amongst peasants, since they were most likely to be affected by economic changes (Dányi 1977: 84; Klinger 1980: 76). Concurrently to this decrease resultant from natural checks on fertility, widespread malnutrition and high infant mortality rates were also recorded most strongly in the northern counties (Kovács and Katus 1979:1124).

By the 1900s the fertility rate of small peasant landholders was already significantly lower than those of the landless agricultural laborers and this was one of the main characteristics of the Hungarian demographic transition that differentiated it from Western European countries (Klinger 1964: 281). The fertiltiy rate of the Hungarian landless agricultural laborer strata corresponded to the natural fertilty of the population. Irrespective of how much they worked, their future was without any prospects under the exisiting political and economic order. In contrast to the agricultural laborers, the peasant smallholders limited their number of offspring in order to hold onto the land. This practice was expressed in the saying "One quarter of a plot, one child, we plow but do not sow" [Egy fertály, egy gyerek, Szántunk, de nem vetünk] (Buday 1909: $3,8)$. The uneven population density of the Hungarian counties highlighted political and economic problems, as there was a correlation between natural increase in the birthrate of the northern and eastern counties and emigration. In the peak period of emigration between 1905 and 1907, the outflow of immigrants amounted to 76 percent of the natural increase in birth rates (Puskás 1975: 6, 112). In parts of Hungary a combination of sudden demographic pressure altered the composition of the increased population, giving rise to the number of young people of working age facing a lack of alternative employment opportunities. The Hungarian brief increase of high birth rate producing population growth was poor in comparison with countries like England or Germany, where the same phenomenon lasted a hundred and fifty or a hundred and seventy years, and where - in the nineteenth century alone - the British population increased fourfold, and the German population more than doubled (Cipolla 1973: 29). 
Szántó, Ildikó. "Problems of a Declining Hungarian Birth Rate: A Historical Perspective." Hungarian Cultural Studies. e-Journal of the American Hungarian Educators Association, Volume 7 (2014): http://ahea.pitt.edu DOI: 10.5195/ahea.2014.1

The First World War resulted in a sharp decline in births throughout Hungary, and the "catching up" period after the war, when fertilty rates were usually high in other countries, proved to be relatively short. The figures for the 1920s did not even reach the levels of the prewar years, as the decrease in live births became more marked. The decline in birth rate was in fact faster than the improvement in the death rate, and the expected postwar natural increase gradually fell away up to the beginning of the Second World War. There was on average one percent population increase per annum before the First World War, and even less between 1921 and 1930, and similary the slugish natural population increase continued between 1931 and 1941 (Ránki 1978: 767). By the end of the 1930s the decreasing birth rate indicated that it was insufficient to ensure the reproduction of future generations, although the apparent decline of the natural increase in birthrate was somewhat counterbalanced by the significant decrease in emigration due to the U.S. immigration laws after 1924 (Ránki 1978: 766-767; Klinger 1964: 255). However, the mortality figures still continued to be high in comparison with those of Austria and Germany.

The agricultural crisis of the 1930s and the stagnating economy of the interwar period deeply affected the living standards of the small and medium landholders, who could not suppport large families (Gunst 1987:147). The small and medium landholders' standards of living were invariably affected by the falling agricultural prices, while the conditions for intensive agriculture were also lacking. Furthermore, the unemployment of the 1930s made it almost impossible for peasants or agricultural laborers to enter industry. The impact of the economic crisis of the 1930s was worse in small agrarian countries such as Hungary and the continuing decline of fertility may be explained by the economic and social changes of the interwar years, whilst in addition to this the pace of industrialization had also slowed. The 1930 census provided ample evidence for the conclusion to be made that a significant part of Hungarian society could not produce enough offspring for the simple reproduction of the parents' generation. The low birth rate figures of the small and medium landholders as well as of the urban population was masked by the consistently high birth rate of one group, the landless agricultural laborers, who comprised two-thirds of the population and partially compensated for the other social groups, but still not enough to ensure the reproduction of future generations (Klinger 1964: 283; Andorka 1987: 322-323).

In the 1930s the issue of the low birth rate of a large segment of the population generated a burst of publications. Intellectuals, writers, and sociologists, who were called "the village researchers," highlighted the social and economic ills of the small peasant landholders as well as the plight of the landless agricultural laborers (Illyés 1933: 17-18; Hídvégi 1938: 213). The problems of these populations were due not only to the uneven distribution of land-526 families owned a third of the agricultural land on which one and a half million farm servants workedbut also the lack of other economic activity of late and slow industrialization. Attempts at democratization to resolve the social and political problems of the country, including those of land ownership, first within a liberal and then within a socialist framework, in 1918 and 1919 respectively, failed. The "traditional" historic elements of society retained political power untill 1945 (Bibó 1981: 273, 275).

The second stage of the Hungarian demographic transition period, between 1945 and 1960, was uneven in view of both decreasing and increasing birth rates. Initially it was affected by a loss of population in the Second World War, which was followed by limited postwar growth. The Second World War resulted in enormous loss of life, the country lost close to seven percent of its population as a direct result of the war and this may have amounted to nearly eight 
Szántó, Ildikó. "Problems of a Declining Hungarian Birth Rate: A Historical Perspective." Hungarian Cultural Studies. e-Journal of the American Hungarian Educators Association, Volume 7 (2014): http://ahea.pitt.edu DOI: 10.5195/ahea.2014.1

percent of the population if the loss of fertility is also counted (Szabó 1989: 73). In addition to lost life, the war - as elsewhere in Eastern Europe - touched off a major migratory movement. (Szepesi 1986: 19; KSH 1987: 9). If the migratory movement from Hungary is also included, an overall loss of ten percent of the population has been accepted by demographers (Siegel 1958: 32; Dávid 1980: 97). This meant that the civilian losses alone amounted to four times the European average, which was excluding the impact of the Holocaust (Braham 1981: 1144; Stark 1985: 94; Nagy 1984: 209). During the war years and even in 1946, the number of births was lower than in previous years, although the birth rates did not decline as significantly in Hungary, Czechoslovakia, and Bulgaria as elsewhere in Eastern Europe (Besemeres 1980: 31). In comparison, the Soviet Union, Poland, and most of Yugoslavia have to be grouped separately in Eastern Europe, as fertility remained at very high levels for a long period after the war (Andorka 1978: 132). Poland, which had suffered the greatest losses in total population of any country in the region - apart from the Soviet Union — had a spectacular baby boom immediately after 1945 which persisted for a full decade before subsiding (Besemeres 1980: 32).

The rise of postwar birth rates were similar in most East-Central European countries where peak figures were reached by 1955, whilst in most Western European states record births were registered around 1960 (Andorka 1978: 120). There was a postwar "baby boom" in Hungary too, though it was modest compared to other East-Central European countries, lasting only for three years between 1947 and 1950, and declining from then on, except in 1953 and 1954 (Andorka 1987: 280). In comparison with Western European or some of the Eastern European figures, the Hungarian birth rate started to increase after 1946, but only to a small extent: 21 live births per thousand people between 1947 and 1950, when it reached the prewar figure, and it fell away in 1951-52 to 20 per thousand (Szabady 1975: 169-171). In Hungary as in Czechoslovakia, the number of live births began to decline from 1950 onwards; consequently, the government with pro-natalist intent reinforced the existing law, forbidding surgical abortions. It was partly due to this measure that the crude birth rate increased again in 1953 and 1954, but the birth rate declined by 1956, when this unpopular and ineffective legislation was repealed (Andorka 1987: 79, 280).

Hungarian demographers considered the long term impact of the continuous decrease of the birth rate from the mid-1950s less as a specific Hungarian problem than as a stage that all advanced societies go through as part of their modernization. Nevertheless, by the mid-1960s it was clear that the vast changes that occurred in Hungarian society had mostly affected the agricultural workers, who had traditionally produced the largest families. Urban dwellers and the former small and medium landowners, who became the members of the agricultural cooperatives after 1948, did not alter their prewar low fertility rates, in contrast to the former agricultural workers. According to the surveys, low fertility did not occur simply because of increased social mobility during the 1950s and 1960s, for there was a lower birth rate in each social category, though in the village settlements at least $2.1-2.2$ children were born per woman, which was the minimum figure to replace the existing parent population (Andorka and Harcsa 1982: 186; KSH, Demographic Yearbooks 1978: 186; 1970 census, Andorka 1987:338). The cause of such a general decrease of birth rate might have been explained by the cumulative effects of economic and social changes and/or the large scale adoption of new values, with an emphasis on individuality and a secular outlook on life as accompanying factors in the process of modernization which applied to society at large.

The census data of the post-transitional demographic decades of 1960-1980 highlighted the decline in the natural increase in birthrate and the effect of the economic and social changes 
Szántó, Ildikó. "Problems of a Declining Hungarian Birth Rate: A Historical Perspective." Hungarian Cultural Studies. e-Journal of the American Hungarian Educators Association, Volume 7 (2014): http://ahea.pitt.edu DOI: 10.5195/ahea.2014.1

of the post-1945 era. The birth rate figures in the 1955-1965 census might have been explained by the effects of urbanization, the large number of women entering the workforce, social mobility and cultural changes within society, higher educational opportunities for women, erosion of traditional values, increased divorce rates, availability of modern birth control and even the traumatic impact of the 1956 events. By1960 less than sixty percent of the population lived in villages and by 1978 less than half of the population, which meant that a significant segment of the rural population decreased markedly as the result of industrialization, with its shift towards urban centers and to non-agricultural jobs indicating a new kind of social orientation (Szabady 1961:15).

Urbanization and concomitant social mobility was often connected with migration, and the latter was particularly intensive in postwar Hungary, especially in the 1960s (Andorka and Harcsa 1982: 182). According to the 1962-64 surveys of fertility differences, it was found that the main direction of social mobility was from the peasant into the industrial stratum, and to a lesser extent, from the peasant into the professional stratum. The results of the 1962-64 surveys showed that mobile couples entering from one traditional high fertility stratum into another did not necessarily maintain their fertility in the new stratum (Andorka 1978: 276). By the late 1960s it had become characteristic for the children of farming families to learn a trade at a young age and to begin to work outside agriculture, and these worker households or mixed worker-peasants households which were affected by an urban influence had an adverse impact on the fertility in village or rural settlements in close proximity to towns (Andorka 1969: 30; Harcsa 1980: 138139).

Political and economic changes caused the agricultural workers and the cooperative peasant class' income to reach or approach the income level of other classes and sections of society, and thereby ended the centuries-old handicap under which they had suffered (Matolcsy 1938: 29). In about three decades, two-thirds of the adult population had changed their social positions compared with that of their fathers, and this had a lasting effect on reproduction. While the social mobility of men from industrial and agricultural backgrounds into professional and clerical occupations slowed down by the early 1960s, the social mobility of women increased as a result of educational opportunities. They then conformed to the life-style and expectations of the strata into which they moved. This was particularly noticeably demonstrated by the changes to their family planning approaches and resultant patterns of fertility (Andorka 1982: 253). By the mid- and late 1960s the average size of the family fell below three; and this period of stagnating birth rate coincided with the maximum level of employment of women on the eve of new economic development, with the desired number of children averaging at $2.25-2.33$ children per fertile woman (Szepesi 1986: 36,71; Miltényi and Szabady 1964: 304).

The decreasing fertility rate of the 1960s and consequent smaller families forced the government to work out a long-term population policy. In 1965 the government introduced an increased family allowance, followed by the Child-Care Allowance in 1967. The 1973 Central Committee's resolution enacted a comprehensive population policy to ensure at least the future replacement of the parent's generation with the target of an average of 2.3 children to be born to each family (Andorka 1987: 288). The welcome effects of the generous population policy and a less liberal view of terminating pregnancies formulated in the 1974 Act, compared to the period of no restrictions of induced abortions between 1956 and 1974, showed a marked increase in the fertility rate. However, this may be interpreted through recourse to young women advancing the births of their first child, though in addition the number of desired children also increased after 
Szántó, Ildikó. "Problems of a Declining Hungarian Birth Rate: A Historical Perspective." Hungarian Cultural Studies. e-Journal of the American Hungarian Educators Association, Volume 7 (2014): http://ahea.pitt.edu DOI: 10.5195/ahea.2014.1

1966, which was to only fall back from the mid-1970s onwards (Andorka, Kolosi, and Vukovich 1992: 17, 23).

On the whole, from the 1960s and 1970s living standards improved markedly, particularly in families with more than one wage earner per family, where the number of wage earners outstripped the number of dependents (Frigyes 1964: 765). The 1960s and the 1970s coincided with the period of restructuring of the economy in the course of socioeconomic transformation and further increased the level of women in the workforce. Female employment, which had continuously grown till the 1970s, made up nearly half of the Hungarian labor force by 1978 (Huszár and Surányi 1980: 126). Similarly to the Hungarian surveys, comparative fertility studies of working women in socialist countries in the same period suggest that one of the effects of the low birth rate in this period is possibly related to the high level of employment of women, especially as the spacing and timing of births were concerned (Barta, Klinger, and Miltényi 1985: 25). At the same time the studies from the 1960s seem to suggest that there was no direct negative impact of education on fertility; on the contrary, employed women, particularly women with university degrees, had a slightly higher fertility rate than women with only secondary education (Klinger 1969: 1180).

Following the peak year of 1975 - which had the highest natural increase in population since 1962 - the number of live births began to decrease again from 1977 on, and continued to fall to the level of 1960. By 1981 the trend of fertility continued to decline markedly below the level necessary for the long term reproduction of the population (Andorka 1987: 287-288, 338). There were three main reasons for the falling birth rate in the 1980s: first, the age groups which were most likely to contract marriages were smaller; second, a certain proportion of marriages had been delayed; third, the proportion of divorces increased among women of child-bearing age by some 50 percent (Klinger 1981: 24). The low figures for live births from 1980 onwards indicated that the older generation, those who had already given birth to one or two children, did not give birth to another child (Klinger, Bárány, Mészáros 1982: 288). The reason for the downward modification of planned family sizes were invariably connected with that of the socioeconomic status of these couples particularly context of issues such as health problems, financial and housing difficulties (Pongrácz and Molnár 1979: 308). In contrast to the previous decade, by the 1980s real wages fell substantially as economic growth came to a halt and young people faced a far more difficult situation in both housing and employment. The birth rate reached a critically low figure by 1982, and declined even further in the following decades.

The dramatic decline in fertility continued unabated from the 1980s to 2011, when live births decreased to the lowest level. According to the KSH figures of 2011, 100 women would give birth to only 124 children during their life, much fewer than ever before. It has been estimated, therefore, that at a gross reproduction rate based on the 2011 fertility rate, 1000 women would give birth to 600 daughters during their life time, 40 percent fewer than the number of the parents' generation (KSH Magyar Statisztikai Évkönyv 2013: 46). Concurrently, the number of marriages fluctuated or stagnated in the 2000s, and fell by one fifth between 2006 and 2010 (KSH, 2.2012: 16). This decrease was even more significant in view of the tendency to delay marriages which also fell by one fifth between 2006 and 2010 and an increase in cohabitating partnerships with less commitment to producing offspring (KSH, 2.2012: 16,78-79). While Hungarian demographic developments from 2000 were similar to those in the former socialist countries, a combination of factors possibly exacerbated the decline in the birth rate in Hungary. 
Szántó, Ildikó. "Problems of a Declining Hungarian Birth Rate: A Historical Perspective." Hungarian Cultural Studies. e-Journal of the American Hungarian Educators Association, Volume 7 (2014): http://ahea.pitt.edu DOI: 10.5195/ahea.2014.1

Following the change to a market economy in 1989, which resulted in the loss of more than a million jobs both in industry and agriculture, employed women faced added disadvantages. Women lost their earlier job security and the guarantee of equal treatment by law, whilst the conflict between family and work was emphasized by the conservative governments. As part of increasing income inequalities - women were receiving 20 percent lower pay on the average than men - the various cutbacks in welfare subsidies, the significantly fewer available free childcare places and the unavailability of part-time employment affect the continuing decline in birth rates (Bartus, Murinkó, Szalma and Szél 2013: 30).

Before 1990 most women were employed; by 2012 the employment rate of Hungarian women is one of the lowest in the EU, a little over 56 percent of the total female working population. Less than 10 percent work part-time, compared to the 36 percent of women in parttime jobs in the Eurozone countries (Fodor 2013). In addition, the Hungarian birth rate was also affected by changes in values and attitudes in partnership behavior well before the collapse of socialist system (Spéder and Kamarás 2008: 604).

Summarizing, the Hungarian demographic studies highlight the fact that the decline in birth rate is not a recent phenomenon, but the result of a long-term process that began at the end of the nineteenth century. Hungary was a latecomer to industrialization which was accompanied by a short burst of population growth between 1886 and 1905 .

The Hungarian increase of high birth rate leading to population growth was poor in comparison with countries like England or Germany, where the same phenomenon lasted 150 or even 170 years, and where - in the nineteenth century alone - the British population increased fourfold, and the German population more than doubled (Cipolla 1973: 29). In addition, the Hungarian period of demographic transition, between 1880 and 1960, coincided with an enormous population loss stemming from both world wars.

One of the marked differences in birth rate between Hungary and Western European countries was that the number of offsping of the Hungarian small and medium landholders started to decline before the turn of the century, indicating widespread birth control within marriage. By the 1930s the censuses provided ample evidence that a significant part of Hungarian society could not produce enough offspring for the simple reproduction of the parents' generation. The low birth rate figures of the urban population as well as of the small and medium peasant landholders, were masked by the consitently high birth rate of the agricultural manual workers, who comprised two-thirds of the population until the 1940s. By the 1950s, these socio-occupational differences between agricultural manual strata and the urban population declined as a result of the political and economic changes wihtin Hungarian society. Rapid social and economic changes affected Hungarian society over three decades, from 1950 till 1980 in which two-thirds of the adult population had changed their social positions compared with their fathers. Such social mobility had a lasting effect on reproduction, as half of the agricultural manual workers moved to a new stratum and adopted the accepted smaller family model of the industrial and professional strata.

The decrease in birth rate reached the lowest levels in 1962; as result, the socialist government was forced to increase the family allowances and introduced a most generous, comprehensive family support system. Consequently Hungarian birth rates peaked in 1975, declining again by the 1980s to a level even lower than those reached in the1960s. For the first time in 1999 the TFR number was 1.28, which is below 100,000 live births, and the downward trend continued in the current decade also, where the birth rate remains as low as 1.3. 
The population of Hungary dropped below ten million in 2010, based on KSH statistics, which is a reminder that Hungary's population is aging and, eventually, the number of pensioners will be higher than the number of those of working age, with the implication relating to the possible collapse of the pension system. The current government intends to focus on needs of families. One of its election promises is the substantial increase in the family tax allowance system, which has been restructured and extended to lower-income earners. In addition to claiming a Child Care Allowance, it will be possible for a mother to enter employment after her child's first birthday while keeping the Child Care Allowance allocated after a newborn (Focusing on Hungary, Századvég Foundation, January 2014/1).

\section{Appendix A}

\begin{tabular}{|c|c|c|}
\hline Total fertility rate & Year & Total fertility rate \\
\hline 1900-1901 5.28 & 1970-1975 & $2.09 \Delta$ \\
\hline 1910-1911 4.67 & 1974-1977 & $2.28 \triangle$ \\
\hline ק & 1975-1980 & $2.12 \nabla$ \\
\hline 1930-1931 2.84 & 1980-1985 & $1.81 \nabla$ \\
\hline 1940-1941 2.48 V & 1985-1990 & $1.82 \triangle$ \\
\hline 1948-1949 2.56 & 1990-1995 & $1.73 \nabla$ \\
\hline 1950-1955 2.73 & 1995-2000 & $1.38 \nabla$ \\
\hline 1955-1960 2.21 & 2001-2005 & $1.30 \nabla$ \\
\hline 1960-1965 1.82 & 2006-2010 & $1.32 \triangle$ \\
\hline ه & 2012 & $1.34 \Delta$ \\
\hline
\end{tabular}

\section{Total fertitlity rate}

KSH, Vital statistics, Hungarian Central Statistical Office, 2011. 


\section{Appendix B}

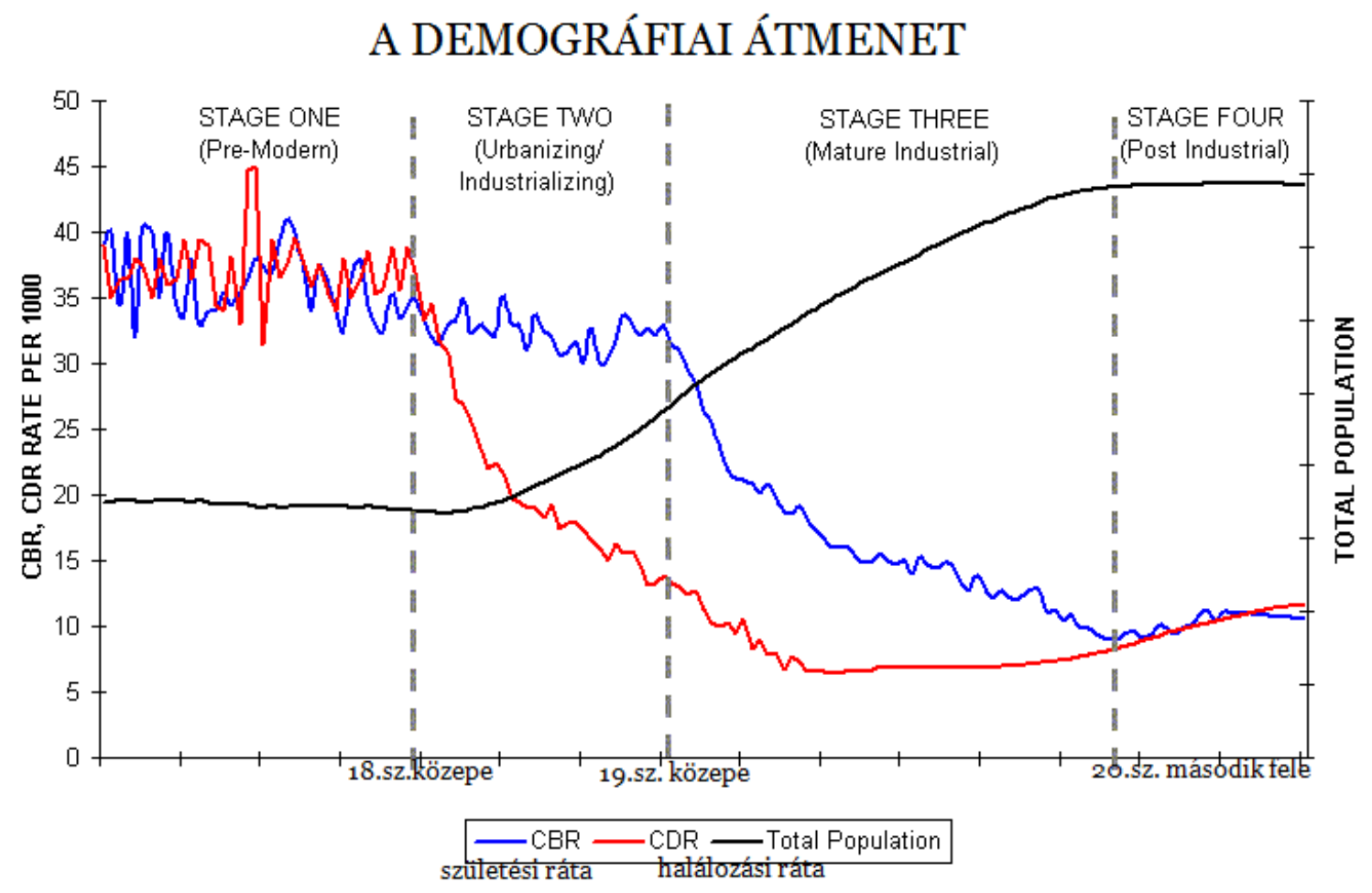

\section{The Demographic Transition}

(the blue line indicates birth rate, the red line indicates death rate)

Source: 1715-2008 Historic estimates and censuses for the total population in the territory of present-day; Hungary. Vital statistics, Hungarian Central Statistical Office 
Szántó, Ildikó. "Problems of a Declining Hungarian Birth Rate: A Historical Perspective." Hungarian Cultural Studies. e-Journal of the American Hungarian Educators Association, Volume 7 (2014): http://ahea.pitt.edu DOI: 10.5195/ahea.2014.1

\section{Works Cited}

Acsády, Ignác. 1896. Magyarország népessége a Pragmatica Sanctio korában 1720-21 [“The Population of Hungary at the age of the Pragmatic Sanction 1720-21']. Magyar Statisztikai Közlemények, VII. ['Hungarian Statsitical Reporting'] Budapest: Pesti Kiadó.

Andorka, Rudolf. 1969. “A születésszám gazdasági és társadalmi tényezői Magyarországon” ['Economic and social factors of birthrate in Hungary']. Valóság 3: 26-39.

- 1978. Determinants of Fertiltiy in Advanced Countries. London: Methuen.

—. 1982. A társadalmi mobilitás változásai Magyarországon ['Changes in social mobility in Hungary']. Budapest: Gondolat Könyvkiadó.

—. 1987. Gyermekszám a fejlett országokban. ['Determinants of fertility in advanced countries']. Budapest: Gondolat Könyvkiadó.

Andorka, Rudolf and István Harcsa. 1982. "A községi népesség társadalomstatisztikai leírása" ['The statistical description of a Hungarian village in contemporary Hungarian society']. In A falu a magyar társadalomban ['The village in Hungarian society']. Ed. Vágvölgyi, András. Budapest: Akadémiai Kiadó.

Andorka, Rudolf, Tamás Kolosi, and György Vukovich, eds.1992. Social Report. Budapest: TÁRKI Social Research Institute.

Bartus, Tamás, Lívia Murinkó, Ivett Szalma, and Bernadett Szél. 2013. “The Effect of Education on Second Births in Hungary: A Test of the Time-Squeeze, Self-Education and PartnerEffect Hypotheses." Demographic Research 28/1: 1-32. http://www.demographicresearch.org/Volumes/Vol28/1.

Besemeres, John. 1980. Socialist Population Politics. London: Sharpe.

Bibó, István. 1981. Összegyüjtött munkái ['Complete Works']. Münich: Europai Protestans Szabad Egyetem-Bern.

Braham, Randolph L. 1981. The Politics of Genocide: The Holocaust in Hungary. 2 vol., 2nd ed. New York: Columbia University Press.

Cipolla, Carlo M., ed. 1973. The Fontana Economic History of Europe. The Industrial Revolution. N.p.: Fontana.

Buday, Dezső, 1909. "Az egyke” ['The only child']. Huszadik Század 2/38: 3-17.

Dányi, Dezső. 1960. “Az 1777. évi telkek összeírása” ['The 1777 census']. In Történeti statisztikai évkönyv ['Historical Statistical Yearbook']. Budapest: SKV.

— 1977. "Regionális fertilitási sémák Magyarországon a 19. század végén" ['Regional fertitlity patterns in Hungary at the end of the $19^{\text {th }}$ century']. Demográfia. 20/1: 56-87.

Dávid, Zoltán. 1980. "A magyar nemzetiségi statisztika múltja és jelene" ['The past and present statistics of the Hungarian nationalities']. Valóság: 8.

Demény, Paul. 1972. "Early Fertility Decline in Austria-Hungary: A Lesson in Demographic Transition." East-West Population Institute Reprint.25. Honolulu: East-West Center.

Fodor, Éva. 2013. The Policy on Gender Equality in Hungary. European Parliament. www.europarl.europa.eu/studies.

Focusing on Hungary. Budapest: Századvég Foundation, January 2014/1.

Frigyes, Ervin. 1964. “A munkás és az alkalmazott jövedelmi rétegződése legfontosabb 
Szántó, Ildikó. "Problems of a Declining Hungarian Birth Rate: A Historical Perspective." Hungarian Cultural Studies. e-Journal of the American Hungarian Educators Association, Volume 7 (2014): http://ahea.pitt.edu DOI: 10.5195/ahea.2014.1

tényezöi' ['Principal factors of stratification of the workers and employees by income']. Statisztikai Szemle 42/7: 748-766.

Fülep, Lajos. "Riport és cikkek" ['Reports and articles']. Pesti Napló [Pest Journal]. 10th November, 17th November, 26th November 1929, 4th December,15th December 1929.

Gunst, Péter. 1987. A paraszti társadalom Magyarországon a két világháború között ['Hungarian peasant society in the interwar period']. Budapest: MTA Történettudományi Intézet.

Hajnal, John. 1965. "European Marriage Patterns in Perspective." In Population in History:essays in historical demography. Eds. Glass and Eversley. Population in History: Essays in Historical Demography. London: Arnold: 101-143.

Hídvégi, János.1938. A hulló magyarság ['The disappearing Hungarians']. Budapest: Atheneum. Harcsa, István. 1981. "A vándorlás és a nemzedékek közötti mobilitás” ['Migration and inter generational mobility']. Statisztikai Szemle 59/2: 135-165.

Huszár, Mária and Bálint Surányi. 1980. "The Employment of Women.” The New Hungarian Quarterly 21/77: 125-131.

Illyés, Gyula.1933. “A magyarság pusztulása” ['The disapperance of Hungarians’] Nyugat. ['The West'] 20: 337-344.

Jászi, Oszkár. 1986. A nemzeti államok kialakulása és a nemzetiségi kérdés ['The development of nation state and the nationalities']. Budapest: Gondolat.

Kapitány, Balázs and Zsolt Spéder. 2012. Demographic Portrait of Hungary 2012: Report on the Conditions of the Hungarian Population, Fertility. Demographic Research Institute. Budapest: Hungarian Central Statistical Office (HCSO): 31-43.

Kiss, Z. Géza. 1986. “A földesúri birtok és parasztföld elkülönösítésének történeti útja az Ormánságban 1767-1867” ['The history of appropriation of common lands by large estates between 1767 and 1867 in the Ormánság']. Századok. 1: 1-99.

Klinger, András. 1964. "A differenciális termékenység újabb alakulása" ['Recent trends in differential fertility']. Demográfia. 7/3-4: 394-408. . 1964. "Differenciális termékenység" ['Differential fertility']. In Bevezetés a demográfiába ['Introduction to demography'] Ed. Egon Szabady. Budapest: Közgazdasági És Jogi Kiadó: 280-292. 1969. Magyarországi népesedés helyzete at 1960-as években ['The demographic situation of Hungary in the 1960s']. Statisztikai Szemle 47/12: 1171-1188. . 1980. "A megyék termékenység arányai az utolsó 150 évben" ['The fertility rate of the counties in the last 150 years']. Statisztikai Szemle. 58/1: 74-85. . 1981. "Népesedés - a népesedéspolitika és eszközei" ['Population and the implementation of population policy] Társadalmi Szemle 1981/3: 20-32.

Klinger, András, Lajos Bárány, and Árpád Mészáros. 1982. World Fertility Survey: Hungary. Working Paper. Budapest: KSH ['Hungarian Central Statistical Office'].

Knodel, John. 1974. The Decline of Fertility in Germany, 1871-1939. Princeton: Princeton UP.

Kodolányi, János. 1922. "Sötétség" ['Gloom']. Nyugat ['The West']: 17-18.

Kovács, Endre and László Katus László, eds. 1979. Magyarország története 1848-1890 I-II. ['History of Hungary 1848-1890']. Budapest:Akadémiai Kiadó.

Kovacsics, József, ed. 1963. Magyarorszdg történeti demográfiája ['Historical Demography of Hungary']. Budapest: Közgazdasági és Jogi Könyvkiadó.

KSH Népességtudományi Kutatóintézet ['Hungarian Central Statistical Office Demographic 
Szántó, Ildikó. "Problems of a Declining Hungarian Birth Rate: A Historical Perspective." Hungarian Cultural Studies. e-Journal of the American Hungarian Educators Association, Volume 7 (2014): http://ahea.pitt.edu DOI: 10.5195/ahea.2014.1

Institue']. 1978. Demographic Yearbooks of 1960-1978. Budapest: KSH.

-1987. Demographic Yearbooks of 1978-1986. Budapest: KSH.

KSH ['Hungarian Central Statistical Office']. 2012. 2011. Évi Népszámlálás 2. Elözetes adatok [Preliminary data of the population census 2011]. Budapest:KSH.

—. 2013. 2011. Évi Népszámlálás 4. Demográfiai adatok [2011. Population Census 4. Demographic data]. Budapest:KSH.

. 2013. Magyar statisztikai évkönyv, 2012 [Statistical Yearbook of Hungary, 2012]

Budapest. www.ksh.hu/shelf

Lendvai, Paul. 2003. The Hungarians. London: Hurst and Company.

Lengyel Cook, Maria Sophia and Richard Repetto. 1982. "The Relevance of the Developing Countries to Demographic Transition Theory: Further Lessons from the Hungarian Experience." Population Studies 36: 105-128.

Marczali, Henrik. 1888. Magyarország története II. József korában 1882-88 ['Hungary in the reign of Joseph II]. Vol. 3. Budapest: Pfeifer F. Kiadása.

Matolcsy, Mátyás. 1938. A magyarországi jövedelem- és adótehermegoszlás. ['The distribution of income and level of taxation']. Budapest: Universitas könyvkaidó részvénytársaság.

Mérei, Gyula and Károly Vörös, eds. 1980. Magyarország története 1790-1848 ['The History of Hungary']. Vol 5.1 Budapest: Akadémiai Kiadó.

Miltényi Károly and Egon Szabady. 1964. “Az abortuszhelyzet Magyarországon: demográfiai és egészségügyi összefüggések" [ 'Demographic and medical aspects of abortion in Hungary']. Demográfia. 7/2: 303-309.

Nagy, Kázmér. 1984. Elveszett alkotmány. A magyar politikai emigráció. ['The Lost Constitution. Hungarian Political Exiles']. Budapest: Gondolat.

Pongrácz, Tiborné and Edit Molnár. 1979 "A harmadik gyerekkel kapcsolatos családtervek alakulása" ['Family planning in respect of the third child']. Demográfia 22/4:304-320.

Puskás, Julianna.1975. Emigration from Hungary to U.S. before 1914. Budapest: Akadémiai Kiadó.

Ráth, Zoltán. 1983. Népszaporodásunk kérdése a XX. század küszöbén. ['The issue of population growth at the turn of the century']. Budapest: MTA.

Ránki, György, ed. 1978. Magyarország története 1918-1919, 1919-1945. ['History of Hungary 1918-1919, 1919-1945']. Budapest: Akadémiai Kiadó.

Spéder, Zsolt and Kamarás, Ferenc. 2008. "Hungary: Secular fertility decline with distinct period fluctuations." Demographic Research. 19/18: 599-664.

Sorokin, Pitrim A. 1966. Sociological theories of today. New York: Harper Lee.

Siegel, Jacob S. 1958. Population of Hungary. Washington: Government Printing Office.

Stark, Tamás. 1985. "Meghalt, eltünt, fogságba esett. Magyarország második világháborús katonai és polgári embervesztesége"['Hungary's military and civilian losses in the Second World War']. Történelmi Szemle [Hungarian Historical Review]1: 80-94.

Szabady, Egon. 1961. "Magyarország népességének foglalkozási összetétele "['Occupational structure of Hungary's population. Demográfia. 4.1.15. Budapest: KSH. -1975. "A népesség reprodukciója, a termékenység alakulása az elmúlt harminc évben" ['Population, reproduction, fertility trends in the last thirty years']. Demográfia. 18/23:163-179.

Szabó, Miklós.1989. Politikai kultúra Magyarországon 1896-1986. ['Political culture in 
Szántó, Ildikó. "Problems of a Declining Hungarian Birth Rate: A Historical Perspective." Hungarian Cultural Studies. e-Journal of the American Hungarian Educators Association, Volume 7 (2014): http://ahea.pitt.edu DOI: $10.5195 /$ ahea.2014.1

Hungary, 1896-1986']. Budapest: Atlantis Program.

Szepesi, György.1986. Népesedésünk ma és holnap ['Our present and future population']. Budapest: Kossuth Könyvkiadó.

The World Factbook - Central Intelligence Agency

https://www.cia.gov/library/publications/...world-factbook/...2119rank.h. 